anales de psicología, 2017, vol. $33, \mathrm{n}^{\circ} 3$ (october), 568-577 http://dx.doi.org/10.6018/analesps.33.2.265621
C) Copyright 2017: Servicio de Publicaciones de la Universidad de Murcia. Murcia (Spain) ISSN print edition: 0212-9728. ISSN web edition (http://revistas.um.es/analesps): 1695-2294

\title{
Hedonic and eudaimonic well-being in old age through positive psychology studies: a scoping review
}

\author{
Lia Araújo ${ }^{1,2, *}$, Oscar Ribeiro ${ }^{1,3,4}$ and Constança Paúl ${ }^{1}$ \\ 1 UNIFAI/ICBAS and CINTESIS, University of Porto (Portugal). \\ 2 ESEV and CI\&DETS, Polytechnic Institute of Viseu (Portugal). \\ 3 Higher Institute of Social Service of Porto (ISSSP) (Portugal). \\ 4 University of Aveiro (Portugal).
}

Título: Bienestar hedónico y eudaimónico en la vejez a través de estudios
psicológicos positivos: una revisión de alcance.
Resumen: El estudio del envejecimiento a través de la lente de la Psicolo-
gía Positiva permite mirar más allá de la disminución normalmente asociada
con el avance de la edad y considerar experiencias y estrategias gratificantes
para promover un envejecimiento con propósito. Con el objetivo de reunir
evidencia sobre los principales avances conceptuales y empíricos que ilus-
tran el compromiso de la Psicología Positiva con los temas del envejeci-
miento, se llevó a cabo una revisión de alcance. Los artículos que tenían
"Psicología Positiva" y "Envejecimiento" (o palabras similares al envejeci-
miento) en su título, resumen o palabras clave fueron examinados en bases
de datos principales y se buscaron términos relacionados con el envejeci-
miento en revistas bien conocidas de psicología positiva. Esta estrategia
arrojó 48 artículos, 33 trabajos científicos originales y 15 revisiones. Se pre-
sentan los principales temas, diseños de estudio e instrumentos y se discu-
ten los puntos fínales de acuerdo con la perspectiva hedónica o eudaimóni-
ca de los estudios. Se destacan las direcciones futuras relacionadas con la
importancia de constructos comprensivos y estrategias metodológicas en el
estudio del avance de la edad.
Palabras clave: Psicología positiva; envejecimiento; hedonismo; EudaimoPalabras clave: Psicología positiv

\section{Introduction}

Positive Psychology has emerged in recent years as a breath of fresh air. The focus on positive aspects of human experience, like positive subjective experience, positive individual traits, and positive institutions, has been overcoming the traditional models based on pathology that had dominated different disciplines over the years (Seligman \& Csikszentmihalyi, 2000). Although positive psychology has roots in the humanistic psychology, which focused heavily on happiness and fulfillment, it was only in the end of 20st century that it began as a new area of psychology. This branch of psychological sciences has been recognized thanks to several achievements of a core group of researchers and professionals that succeeded the establishment of positive psychology networks and research centers, and other structural elements of a structured discipline as the publication of books, journal special issues and journal articles, themed conferences, specific graduated courses, among others (Linley, Joseph, Harrington, \& Wood, 2006). Nevertheless, despite this great scientific development there are still inconsistencies and opposing perspectives about what well-being is, and how posi-

* Correspondence address [Dirección para correspondencia]

Lia Araújo. UNIFAI, Department of Behavioral Sciences, Institute of Biomedical Sciences Abel Salazar, University of Porto. Rua de Jorge Viterbo Ferreira, n. ${ }^{\circ}$ 228, 4050-313 Porto (Portugal).

E-mail: liajaraujo@esev.ipv.pt
Abstract: The study of aging through the lens of Positive Psychology allows looking beyond the decline normally associated with advancing of age and to consider rewarding experiences and strategies to promote a meaningful aging. In order to gather evidence on the key conceptual and empirical advancements that illustrate the commitment of Positive Psychology with aging issues a scoping review was conducted. Papers having "Positive Psychology" AND "Aging" (or similar words to aging) on their title, abstract or key-words were screened across main databases and aging related terms were searched in well-known journals of positive psychology. This strategy yielded 48 articles, 33 original scientific papers and 15 reviews. Main themes, study designs and instruments are presented and the endpoints are discussed according to the hedonic or eudaimonic perspective of the studies. Future directions related with the importance of comprehensive constructs and method approaches in the study of advancing age are highlighted.

Key words: Positive Psychology; aging; hedonism; eudaimonia; well-being; scoping review.

tive psychology should be approached (Gallagher, Lopez, \& Preacher, 2009).

One of the most controversial issues in the study of positive psychology is the disagreement between hedonic and eudaimonic perspectives regarding concepts and pathways to well-being (Keyes, Shmotkin, \& Ryff, 2002). This separation has its origins in philosophical traditions that are clearly different. The hedonic well-being arises in Greece, fourth century B.C, and is understood as the pursuit of sensation and pleasure (Ryan \& Deci, 2001). Here, subjective well-being (SWB) is the most widely used approach, encompassing three core components: life satisfaction, the presence of positive mood, and the absence of negative mood (Diener, Suh, Lucas, \& Smith, 1999). On the other hand, the eudaimonic perspective has its roots in Aristotle's postulations, and presents well-being as the realization of one's true potential (Ryan \& Deci, 2001). The psychological well-being (PWB) is one of the most accepted approaches of eudaimonic wellbeing and according to Ryff's conceptualization, taps six distinct aspects of human actualization: autonomy, personal growth, self-acceptance, life purpose, mastery, and positive relatedness (Ryff \& Keyes, 1995). Although different in their definition of well-being, emergent assumptions point to the importance of valuing simultaneously hedonic and eudaimonic perspectives instead of comparing both, since each one denotes important and complementary aspects of wellbeing (Henderson \& Knight, 2012). 
The emergence of Positive Psychology has already led the field of gerontology into a movement known as "positive aging" which has emphasized the individual responsibility on life satisfaction and happiness at old age (Hill, 2005). Therefore, the long-standing past contributions that had already a focus on positive, healthy and adaptive functioning (Ryff, 2003) were recognized and strengthened. The transition associated with the onset of aging can be particularly difficult and challenging since there may be a number of occurrences such as retirement, a slowdown of activity, the loss of loved ones, perhaps chronic illness, and even acute illnesses or disability (Paúl, 2007). Within a positive approach, studies that investigate the factors associated with a successful, fulfilled and happy aging have emerged in recent years. An example can be the Harvard Medical School's study of adult development which has reinforced many other researchers' conclusions in referring that close, longlasting, and meaningful relationships, as well as engagement in purposeful activities are essential to happiness, and a sense of well-being and a sense of a life well lived in later years (Vaillant, 2002). This focus on successful aging was originally developed by Rowe and Kahn (1997), which stated the three well-known components of success in advancing age: (i) freedom from disease and disability, (ii) high cognitive and physical functioning, and (iii) social and productive engagement. Also the Selective Optimization with Compensation model (Baltes \& Smith, 2003) seeks to deal with agerelated changes and deficits by praising empowerment strategies, based on investment in positive aspects, like resources, styles and behaviors that are adaptive to the new constraints of aging.

The global phenomenon of population aging is a powerful and transforming demographic force with many possible repercussions. The comprehension of its' impacts at the national and global levels as well as the implications in the individual is just in the beginning. People aged 65 or older are projected to grow from an estimated 524 million in 2010 to nearly 1.5 billion in 2050, with most of the increase in developing countries (WHO, 2011). This scenario raises several questions, namely if population aging will be accompanied by a longer period of good health, a sustained sense of wellbeing, and extended periods of activity, or will it be associated with more illness, disability, and dependency. The urgency of rigorous and coordinated research to close gaps in the available knowledge and the need for action based on evidence-based policies have been suggested by international and well-known entities as the National Institute on Ageing (NIA, 2011) and the World Health Organization (WHO, 2011).

A perspective on positive human functioning and growth in later life allows to consider strategies of adaptation and promoting opportunities for positive change through adult life. But much effort in achieving a scientific understanding and developing effective interventions to build thriving in individuals in later life are need. It seems important to have a systematic overview of the investment of Positive Psychology research in the study of aging in order to identify what has been covered by previous scholars, indicate gaps in previous research and route the way forward for further research. For this reasons, a scoping review of scientific articles published over the last decade was conducted.

\section{Method}

Aiming to analyze the research on older persons developed within the framework of Positive Psychology this systematic review inquires the extent, range and nature of the publications of Positive Psychology about aging issues, summarizing research findings and identifying gaps. We are particularly interested in examine the development of hedonic and eudaimonic approaches of well-being. The choose for a scoping review is justified by the nature of this type of literature review, since the purpose was to appraise and summarize the body of available research literature without assessing study quality; furthermore, this review design allows a preliminary assessment of potential size and extent of available studies and to identify the nature and extent of research evidence (Booth, Papaioannou, \& Sutton, 2012).

For this scoping review the methodological framework of Arksey and O'Malley (2005) was used. It is based on five stages: identifying the research question, searching for relevant studies, selecting the studies, charting the data, and collating, summarizing, and reporting the results. Following this steps, a brief search of literature was conducted to identify the most reasonable keywords and research strategy. A search of the electronic databases SCOPUS, Web of Science, PsycINFO and PUBMED was conducted. The terms "Positive Psychology" AND "Aging" and other expressions related to aging (e.g., "later life", "older people", "old age", "elderly") were searched in the title, abstract and keywords across the databases. Only articles from peer-review journals, published in the last ten years (2003-2013) and written in English were searched. In order to broaden the view on the aging-related research, the same criteria were used for searching "Aging" and similar words in recognized journals of the international forum for the science and application of positive psychology (Journal of Positive Psychology, Journal of Happiness Studies and Journal of Psychology of Wellbeing). For selecting the studies, titles, key-words, abstracts and, in some cases, the full article was read. Bearing in mind this study's main purpose, some exclusion criteria were also applied: documents that were editorials or author's commentaries or had no article available, and had considered samples of individuals aged less than 60 years old were not included in this review (see Figure 1). 


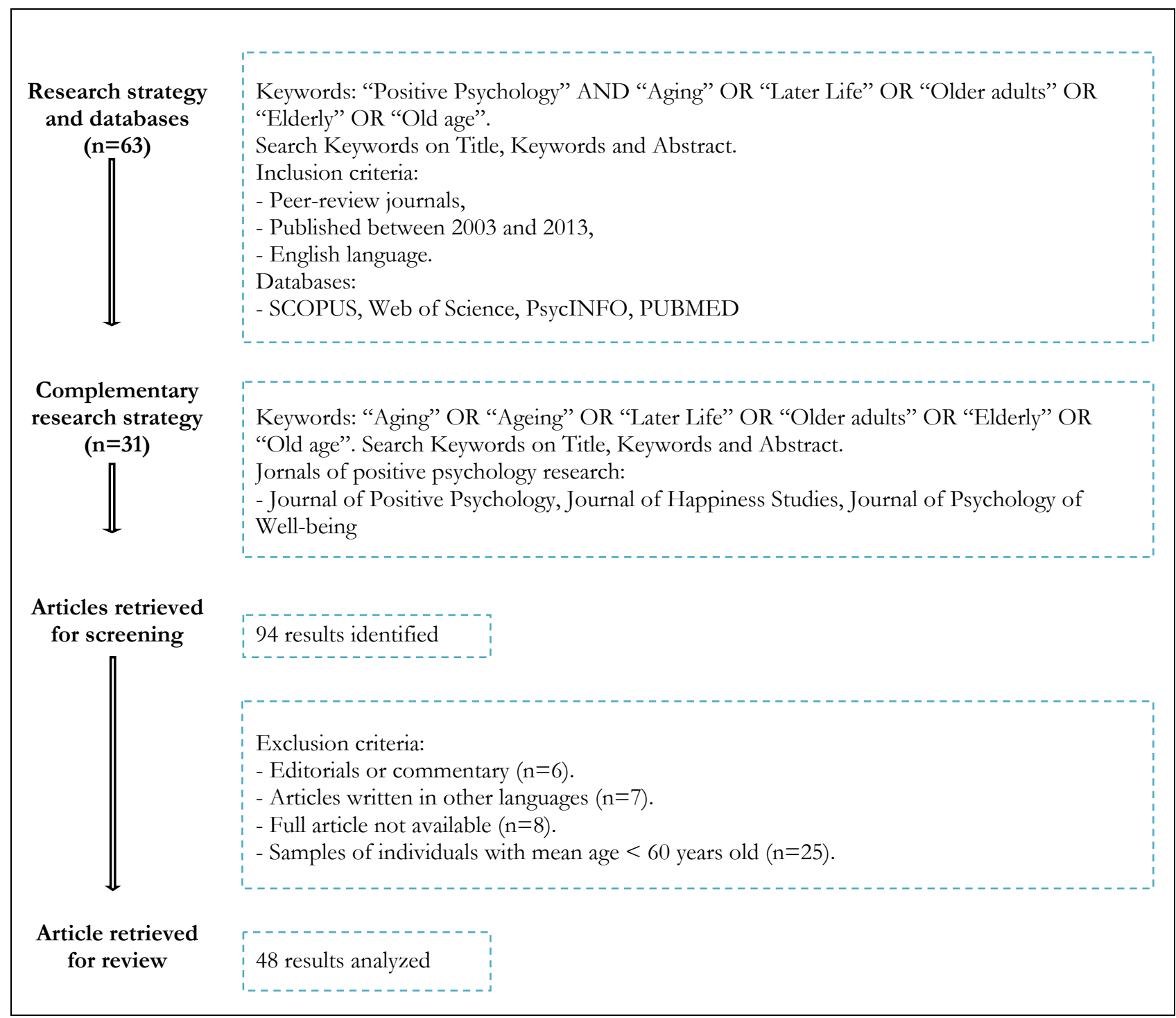

Figure 1. Search strategy and results.

The next stage of the work involved 'charting' key items of information obtained from the primary sources (original scientific papers) and secondary sources (reviews). This procedure, considered "descriptive-analytical method" within the narrative tradition (Arksey \& O'Malley, 2005), involves applying a common analytical framework to all the results and collecting standard information on each study. Information was recorded as follows: positive psychology main domains (usually identified in the title, key-words, or dependent variable), type of study, sample and outcome measures (only for primary researches). Main results/conclusions of the papers were summarized and classified according to their well-being approach: (i) hedonic, (ii) eudaimonic and (iii) integration of both (in primary researches). This process had required the analysis of each paper by two researchers and was guided by important bibliographic sources that clarify the main assumptions of hedonic and eudaimonic approaches (e.g., Ryan \& Deci, 2001; Henderson \& Knight, 2012; Waterman, 1993).

Therefore, the studies with a clear focus on pleasure, happiness, good life, subjective well-being and related topics were classified in the hedonic category and examined as a whole. The same happened with the studies about human potential, personal growth, meaningfulness and other themes that are consistent with a eudaimonic perspective. A third category grouped the studies that sought to combine topics and measures considered by both emotional (hedonic) and psychological (eudaimonic) well-being. At the final stage of collating, summarizing and reporting the results, an attempt was made to identify patterns and directions in the findings, making a new whole out of the parts. The main topics, research methods and domains approached were highlighted, allowing having a framework of the main issues 
covered by Positive Psychology in the field of aging and later life.

\section{Results}

As shown in Figure 1, 94 sources were identified for review. A total of 48 results were ultimately included in the scoping review. Of these, 33 original scientific research articles (primary sources) and 15 results were reviews (secondary sources).

Studies included in this review approached different constructs of well-being and related topics under investigation. The most frequent topics were life satisfaction $(n=11)$, happiness $(n=10)$, subjective well-being $(n=10)$, positive affect $(n=7)$, optimism $(n=6)$, perceived control $(n=5)$, coping $(n=3)$, hope $(n=3)$, psychological well-being $(n=3)$, selfconcept $(n=3)$, sense of coherence $(n=3)$, spirituality $(n=3)$, positive attitudes toward aging $(n=2)$, purpose in life $(n=2)$ and mindfulness $(n=2)$. Altruism and humor emerged in 1 article each one. The last four topics, also referred in 1 publication, were related to very specific approaches to wellbeing and clearly assumed by their authors as emerging themes that should be further studied. These topics and respective references were positive health (Seligman, 2008), positive neurology (Kapur et al., 2013), positive contributory value of older workers (Peterson \& Spiker, 2005) and positive life-span musicianship (Brodsky, 2011).

In relation to the methodology used in the original research articles, 29 used quantitative and 4 qualitative methods, with samples that varied substantially in terms of dimension. Well-being was often considered as outcome or dependent variable in the investigation of factors that were associated with well-being, namely health (e.g., Griffin, Mroczek, \& Spiro, 2006), hope (e.g., Isaacowitz, Vaillant, \& Seligman, 2003) and coping resources (e.g., Tovel, \& Carmel, 2013). Some other studies looked for change in well- being with aging (e.g., Gana, Bailly, Saada, Joulain, \& Alaphilippe, 2013a.). A smaller part considered well-being as a predictor of functioning (e.g., Brummett, Babyak, Grønbæk, \& Barefoot, 2011), as a protector against decline (e.g., Ostir, Ottenbacher, \& Markides, 2004) and as a moderator factor that enables older people to maintain mental health (Wiesmann \& Hannich, 2013b).

As expected, qualitative studies had smaller samples ranging from 8 participants (Baker \& Ballantyne, 2013) to 35 participants (Chaitin et al., 2013). Among quantitative studies the smaller sample had 56 individuals, aged between 60 and 93 years old and with a mean age of 71.2 (Ramírez et al., 2013); the biggest sample had 18345 individuals aged from 50 to 70 years old and with a mean age of 60.4 (Horner, 2012). This variation is related with the purpose and design of these studies, since the first one is about the effect of an intervention program using experimental and control groups, and the other is based on three National and European surveys (SHARE - Survey of Health, Ageing, and Retirement in Europe; English Longitudinal Study of Ageing; Health and Retirement Study). Most quantitative studies $(n=15)$ included samples between 100 and 500 older adults; 3 studies used samples between 500 and 1000; and 10 studies had more than 1000 participants.

In what regards to the data collection methods, a huge diversity of well-being instruments was identified (see Table 1). The Center for Epidemiological Studies Depression Scale (CES-D; Radloff, 1977) and the Satisfaction with Life Scale (Diener, Emmons, Larsen, \& Griffin, 1985) were the instruments more often used, followed by the Scales of Psychological Well-Being (Ryff \& Keyes, 1995) Sense of Coherence Scale (Antonovsky, 1987) and Subjective Happiness Scale (Lyubomirsky \& Lepper, 1999). The other 34 instruments identified were used in only one or two different studies. The use of general questions about happiness and life satisfaction was also found.

Table 1. Summary of instruments from primary sources.

$\begin{array}{ll}\text { Instruments of Well-being } & \text { NReferences }\end{array}$

Center for Epidemiological Studies Depression Scale (Radloff, 1977) 6 Keng \& Wu, 2013; Palgi, 2013; Tweed \& Tweed, 2011; Wood \& Joseph, 2010; Ai, Peterson, Tice, Bolling \& Koenig, 2004; Ostir, Ottenbacher, \& Markides, 2004

Satisfaction with Life Scale (Diener, Emmons, Larsen, \& Griffin, 1985)

6 Gana, Bailly, Saada, Joulain, \& Alaphilippe, 2013a; Gana et al., 2013b; Godoy-Izquierdo, Moreno, Pérez, Serrano, \& García, 2013; Palgi, 2013; Ramírez, Ortega, Chamorro, \& Colmenero, 2013; Oishi, Whitchurch, Miao, Kurtz, \& Park, 2009

Scales of Psychological Well-Being (Ryff \& Keyes, 1995)

4 Kim, Sun, Park, \& Peterson, 2013a; Kim, Sun, Park, Kubzansky, \& Peterson, 2013b; Palgi, 2013; Wood \& Joseph, 2010

Sense of Coherence Scale (Antonovsky, 1987)

3 Cowlishaw, Niele, Teshuva, Browning, \& Kendig, 2013; Wiesmann \& Hannich, 2013a; Wiesmann \& Hannich, 2013b

Subjective Happiness Scale (Lyubomirsky \& Lepper, 1999)

3 Angner, Ghandhi, Purvis, Amante, \& Allison, 2013; Ramírez et al., 2013; Tovel \& Carmel, 2013 


\begin{tabular}{|c|c|}
\hline Instruments of Well-being & NReferences \\
\hline General Self-Efficacy Scale (Sherer \& Adams, 1983) & 2 Godoy-Izquierdo, et al., 2013; Tovel \& Carmel, 2013 \\
\hline $\begin{array}{l}\text { General questions about life satisfaction (e.g., "In general how satis- } \\
\text { fied are you with your life as a whole these days?") }\end{array}$ & $\begin{array}{l}2 \text { Peterson, Chatters, Taylor, \& Nguyen, 2013; Schilling, } \\
\text { Wahl, \& Oswald, } 2013\end{array}$ \\
\hline $\begin{array}{l}\text { General questions about happiness (e.g., "Taking all things together, } \\
\text { how would you say things are these days?") }\end{array}$ & $\begin{array}{l}2 \text { Peterson et al., 2013; Tadic, Oerlemans, Bakker, \& } \\
\text { Veenhoven, } 2013\end{array}$ \\
\hline Life Orientation Test (Scheier \& Carver, 1985) & 2 Godoy-Izquierdo et al., 2013; Ai et al., 2004 \\
\hline Life Satisfaction Index (Neugarten et al., 1961) & 2 Keng, \& Wu, 2013; Tovel, \& Carmel, 2013 \\
\hline Philadelphia Geriatric Center Positive Morale Scale (Lawton, 1975) & 2 Tovel \& Carmel, 2013; Wiesmann \& Hannich, 2013b \\
\hline Positive and Negative Affect Schedule (Watson et al., 1988) & $\begin{array}{l}2 \text { Etezadi \& Pushkar, 2013; Griffin, Mroczel, \& Spiro, } \\
2006\end{array}$ \\
\hline Self-Esteem Scale (Rosenberg, 1965) & $\begin{array}{l}2 \text { Wiesmann \& Hannich, 2013a; } \\
\text { Wiesmann \& Hannich, 2013b }\end{array}$ \\
\hline SF-36 Health Survey (Bullinger, 1995) & $\begin{array}{l}2 \text { Wiesmann \& Hannich, 2013b; Brummett, Babyak, } \\
\text { Grønbæk, \& Barefoot, } 2011\end{array}$ \\
\hline Affect Balance Scale (Warr et al., 1983) & 1 Godoy-Izquierdo et al., 2013 \\
\hline Bradburn affect balance scale-positive emotion (Bradburn, 1969) & 1 Tweed \& Tweed, 2011 \\
\hline Control, Autonomy, Self-realization, and Pleasure scale (Hyde et a & 1 Horner, 2012 \\
\hline
\end{tabular}
2003)

Dutch Scale of Subjective Well-being for Older Persons (Groningen, 1 Koopmans, Geleijnse, Zitman, \& Giltay, 2010

The Netherlands; Tempelman, 1987)

Dispositional Coping Inventory (Carver et al., 1989)

1 Etezadi \& Pushkar, 2013

Generalized Self-Efficacy Scale (Schwarzer \& Jerusalem, 1995)

Goal-Management Scale (Wrosch et al., 2003)

Happiness Scale (Godoy-Izquierdo \& Godoy 2006)

Hope Scale (Snyder et al., 1991)

Life Engagement Test (Scheier et al. 2006)

1 Wiesmann \& Hannich, 2013b

1 Tovel \& Carmel, 2013

1 Godoy-Izquierdo et al., 2013

1 Ai et al., 2004

1 Etezadi \& Pushkar, 2013

Memorial University of New Foundland Scale of Happiness (Kozma 1 Dai, Zhang, \& Li, 2013

$\&$ Stones, 1980)

NEO-PI (for Emotional Instability, i.e., neuroticism) (Costa, \&

1 Tweed \& Tweed, 2011

McCrae, 1985)

Perceived Control Scale (Lachman \& Weaver, 1998)

Personal Wellbeing Index (International Wellbeing Group, 2006)

Positive and Negative Affect (Mroczek \& Kolarz, 1998)

Preparation for Future Care Needs (Sorensen \& Pinquart, 2001)

Questions on Life Satisfaction (Henrich \& Herschbach, 2000)

Religious Involvement Scale (Chatters, Levin, \& Taylor, 1992)

Satisfaction with Life Scale (Carmel \& Mutran 1997)

1 Etezadi \& Pushkar, 2013

1 Broadbent, Quadros-Wander, \& McGillivray, 2013

1 Palgi, 2013

1 Tovel \& Carmel, 2013

1 Wiesmann \& Hannich, 2013a

1 Ai et al., 2004

1 Tovel \& Carmel, 2013

Satisfaction with Life Scale (Pavot, Diener, Colvin, \& Sandvik, 1991) 1 Isaacowitz, Vaillant, \& Seligman, 2003

Spirituality Perspective Scale (Reed, 1987)

State-Trait Anxiety Inventory (Spielberger, 1983)

SOC questionnaire (Freund \& Baltes, 2002)

Three-Dimensional Wisdom Scale (Ardelt, 2003)

Using Private Prayer as a Means for Coping (Ai et al., 2002)

Will To Live (Carmel, 2011)

16-Strength Questionnaire of Values in Action Classification of

Character Strengths (Peterson \& Seligman, 2002)

The main endpoints of primary research were analyzed according to the well-being approach of each study as previously stated: hedonic, eudaimonic and integration of both (Table 2). This categorization of results allowed to identify 16 results with a focus on hedonic well-being, 6 on eudaimonic and 11 on both approaches simultaneously.

As presented in table 2 , in the studies about subjective well-being, health was the topic more frequently investigat- ed. Main results highlight the influence of health and functional competence in happiness and life satisfaction, and to the influence of positive affect and life satisfaction in health. Other topics further studied in association with subjective well-being (in 3 papers each) were: age/longevity, with controversial results about the influence of age in life satisfaction; external resources, with results presenting the influence of social support, family, economic resources and health in- 
surance in subjective well-being; and retirement, showing, for instance, that working older individuals are not happier than nonworking. Another paper evaluated the outcomes of intervention, presenting an increase in life satisfaction and happiness through a program training of autobiographical memory, forgiveness and gratitude; and in another one, that associated personality with affect, was presented that higher level of extraversion contributes to higher levels of positive affect.

Within studies with a clear eudaimonic approach, health as a core topic was present in two papers, with results that point to the contribution of purpose in life in protecting against certain diseases (e.g., stroke). Other topics associated with psychological well-being were: age/longevity, showing that a sense of stability contribute to positive attitudes towards common age-related constraints; external resources, with familial and social characteristics contributing to selfconcept and resilience; intervention, with an art program that had provided opportunities for autonomous engage- ment and congruent self-expression; and religion/spirituality, focusing on the contribution of religious faith to the agency component of hope and dispositional optimism.

Finally, in those studies that gathered hedonic and eudaimonic perspectives of well-being, health retained also a pivotal role, being the topic more often addressed, with findings about the contribution of self-efficacy, sense of coherence, social support and proactive coping to successful aging and mental health even in the presence of decline in health and functioning. Results about topics previously presented (age, external resources, intervention and religion/spirituality), were also found. Specific analysis on the relation between subjective and psychological well-being in advancing age was present in five studies, showing that perceived control, sense of coherence, hope and self-esteem have a contribution to life satisfaction in older adults. Such relation and other associations are presented in Table 2.

Table 2. Summary of main results from primary sources

\section{Hedonic}

Health and Subjective well-being

Health contributes to happiness and life satisfaction; Functional competence contributes to life satisfaction;

Positive affect contributes to a less decline in functional status and better health;

Life satisfaction did not contributes to health;

Psychiatric disorders and mood disorder were associated with life satisfaction.

Age/Longevity and Subjective Well-being

No age-related decline of life satisfaction;

Increase in life satisfaction with age;

Happiness contributes to lower mortality.

External resources and Subjective Well-being

Family and economics contribute to subjective well-being;

National Health Insurance contributes to happiness and life satisfaction;

Positive emotion is associated with more social support received and provided even among people reporting elevated distress.

Personality and Subjective Well-being:

Higher extraversion contributes to higher levels of positive affect and lower neuroticism to higher levels of negative affect.

Intervention and Subjective Well-being

Program training autobiographical memory, forgiveness and gratitude leads to an increase in life satisfaction and happiness.

Retirement and Subjective Well-being

Working older individuals are not happier than nonworking;

Individuals facing formal retirement at age 65 or later experience an increase in subjective well-being;

Retirees who value practicality factors (e.g., easy access to medical services) felt happier.

\section{Eudaimonic}

Purpose in life contributes to prevent and protect against heart disease;

Age/Longevity and Psychological Well-being

A balancing process of re-appraisal enhanced resolution and the sense of stability contribute

to positive attitudes towards common age-related constraints.
N References $(\mathbf{N}=16)$

9 Angner et al., 2013; Dai et al., 2013; Gana et al., 2013b; Peterson et al., 2013; Schilling et al., 2013; Brummett et al., 2011; Griffin et al., 2006; Ostir et al., 2004

3 Gana et al., 2013a; Gana et al., 2013b; Koopmans et al., 2010

3 Dai et al., 2013; Keng \& Wu, 2013; Tweed \& Tweed, 2011

1 Griffin et al., 2006

1 Ramírez et al., 2013

3 Tadic et al., 2013; Oishi, et al., 2009; Horner, 2012 
External resources and Psychological Well-being

1 Chaitin et al., 2013

Familial and social hardships that have been faced contribute to self-concept and resilience.

Intervention and Psychological Well-being

Arts participation contributes to enhance eudaimonic well-being by providing opportunities

for autonomous engagement, growth-related cognitive and creative challenge and congruent self-expression.

Religion/spirituality and Psychological Well-being:

1 Swindells et al., 2013

Religious faith factors contributed to the agency component of hope and dispositional optimism indirectly through the use of prayer as a coping strategy.

\begin{tabular}{lc}
\hline Hedonic and Eudaimonic & N References (N=11) \\
\hline Health and Well-being & 4 Tovel \& Carmel, 2013; \\
Self-efficacy, sense of coherence, social support and proactive coping contribute to success- & Wiesmann \& Hannich, \\
ful aging and mental health even in the presence of decline in health and functioning; & 2013a; Wiesmann \& Han- \\
Physical health contributes to life satisfaction; & nich, 2013b; Wood \& Jo- \\
Low positive well-being contributes to depression. & seph, 2010 \\
Age/Longevity and Well-being & 3 Broadbent et al., 2013; Palgi, \\
No suppression of self-control with age; & 2013; Isaacowitz et al., 2003
\end{tabular}

Old-old participants maintain a higher general positive sense of Psychological well-being than midlife and young-old participants;

Older adults had higher levels of interpersonal and self-regulatory strengths.

External resources and Well-being

Social support contributes to life satisfaction;

Citizenship and loving relationships contribute to life satisfaction.

Intervention and Well-being

Song writing stimulated positive emotions and meaning.

Religion/spirituality and Well-being:

Spirituality contributes to a meaningful appraisal of life situation.

Relationship between Subjective and Psychological Well-being

Primary perceived control contributes to life satisfaction;

Perceived control and life engagement with an increased use of problem focused and posi-

tive reappraisal coping contribute to emotional well-being associated with wisdom;

Affect balance, life satisfaction, sense of autonomy contribute to happiness;

Sense of coherence, everyday competence and self-esteem contribute to life satisfaction;

Hope contributes to life satisfaction.

\section{Discussion}

Taken together the results selected from the search process (Figure 1), we can have a broad picture of the investment of Positive Psychology in aging and later life research over the last 10 years. This review presents important clues on issues recently aroused both at a conceptual and empirical levels related to the definition and measurement of well-being. The look of Positive Psychology towards older age is still much related with happiness and life satisfaction; on the contrary, issues about the meaning and hope at this life stage, as well as the self-concept of an older adult were found to be present, but clearly in a less representative manner. Comparing specifically two of the best known models of well-being, subjective well-being (Diener, Emmons, Larsen, \& Griffin, 1985) for hedonic formulation, and psychological well-being (Ryff \& Keys, 1995) for the eudaimonic, there is a greater emphasis on the first one. Ten of the thirty-three primary sources analyzed had addressed "subjective well-being" as main theme and 6 has used the "Satisfaction with Life Scale"
(Diener et al., 1985). One the other hand, three had specifically referred "psychological well-being" as main topic and four had used the "Scales of Psychological Well-being (Ryff \& Keys, 1995).

Positive psychological traits and resources associated with adaptation to longer life constitute another theme quite examined throughout the studies presented in this review. Optimism, positive attitudes toward aging, purpose in life, resilience and coping as examples of important personal strengths and psychological processes to maintain (or regain well-being in the face of adversity) are extremely important since this life stage is characterized by diverse conditions of challenge and lost (Aldwin \& Igarashi, 2012; Tovel \& Carmel, 2013). Other interesting topics we've identified that are increasingly being studied are religion/spirituality and successful aging. Religion and spirituality have most recently become part of well-being studies as key factors of positive psychological states in old age (Cowlishaw, Niele, Teshuva, Browning, \& Kendig, 2013). Conversely, the concept of successful aging has been studied extensively in last decades, with a high impact in gerontological research, since it as- 
sumes the possibility for continued growth and development in old age. Distinct formulations have been presenting this concept as not only good physical and cognitive functioning (Rowe \& Kahn, 1997), but also associated with the capacity for cognitive growth (Ryff, 1989), life satisfaction (Neugarten, Havighurst \& Tobin, 1961) and adaptation to change and the achievement of personal goals (Baltes \& Smith, 2003). More recently, it seems remarkable to highlight the study of this approach in the presence of decline in health and functioning. Such an approach intends to clarify resources associated with adaptation and, subsequently, be promoted through specific interventions (e.g., Tovel \& Carmel, 2013).

The methodology should also be subject of consideration, namely the lack of qualitative studies which is a finding that deserves some attention since the older population might have sensory and cognitive deficits that can be better overcome through interviews and open questions about well-being issues (Rodgers \& Herzog, 1992). A huge diversity of available well-being instruments was also an astonishing result, which may reflects the lack of congruence in methodologies and the difficulties of a proper comparison of findings across studies, but in other hand it also means the great interest and efforts doing in the field of the wellbeing study. Another fact to deserve mention relates to the three studies on intervention (Ramírez et al., 2013; Swindells et al., 2013; Baker \& Ballantyne, 2013) since they prove that appropriate programs (e.g., song writing, art performance) can enhance well-being in advancing age. Although interesting and with promising results, a greater emphasis on the development of empirically validated interventions aimed to promote flourishing in older adults is required.

The confront between hedonic and eudaimonic endpoints proved to be a challenge since their motivations are often very closely linked, but in most papers it was clear the emphasis in only one perspective. Thus, also in gerontological research there is a tendency to consider separately the two general perspectives. The results also reflected a largely investment in hedonic perspectives, which is justified by Waterman (1993) who argues that this approach enjoy more scientific consensus, as it had been investigated for a longer period. Nevertheless, themes within this eudaimonic perspective were also identified, mainly referring to meaningful pursuits that promote purpose and growth in life. There were also found studies with joint investigations of feelings of happiness and its association with human strengths and virtues that produce an array of meanings in life, which leads to conclude that integrated models, which have been so acclaimed by different authors (e.g., Delle Fave, Brdar, Freire, Vella-Brodrick, \& Wissing, 2011), are being considered. Re-

\section{References}

Ai, A.L., Peterson, C., Tice, T.N., Bolling, S.F., \& Koenig, H.G. (2004). Faith-based and Secular Pathways to Hope and Optimism Subconstructs in Middle-aged and Older Cardiac Patients. Journal of Health Psychology, 9, 435-450. doi: 10.1177/1359105304042352 cent trends are questioning if eudaimonia is a goal to be achieved or is it a means of reaching well-being (CohenMansfield \& Poon, 2011), reinforcing that subjective wellbeing (hedonic) may be reached though psychological wellbeing (eudaimonic). We believe that this subject deserves further research, due its potential on adaptive functioning in aging. Although the goal of this article was not to add further commentary to this debate, it seems important to emphasize the fact that a greater investment in integrated models remains essential in aging studies for detecting differences and synergies among them and their specificities in old age.

\section{Conclusions}

Some reflections about the limitations of this review are required: firstly, a several issue is the restriction to sources related with positive psychology. This approach may exclude important research on well-being in old age that did not mention "positive psychology" or was not published in positive psychology related journals but this scope review aims, precisely, to analyze the specific focus of positive psychology on aging issues. Other limitations are related with the fact that only the databases of scientific papers were searched and probably important results could be found in books and grey literature on the topics under analysis. Also the fact that only English language sources were retrieved and reviewed can be seen as a limitation and must be considered in future reviews. The review did not account for study quality, relaying on peer review. The reconstruction of findings presented in the review did not account for cultural influences, which is something often neglected though an important issue in aging research, since being old has different meanings across family and society organizations.

A final word is to be said on the importance of looking forward our obtained results, and in that sense we believe a special attention is ought to be given to the following aspects: (i) the unique characteristics of later life, as well as the phenomenon of population aging that is occurring in all countries over the world justify a greater investment and attention on issues related to well-being; (ii) new methodological developments concerning multilevel modeling and construct comparisons (hedonism and eudaimonism) and studies with new approaches that are coming up (namely flourishing and optimal experience) must be developed; (iii) the mixed method approach may have more advantages in studies of this kind, since they combine the benefits of validated instruments with the potential of open questions and answers, of particular value to an older population.

Aldwin, C., \& Igarashi, H. (2012). An Ecological Model of Resilience in Late Life. Annual Review of Gerontology \& Geriatrics, 32, 115-130. doi: http://dx.doi.org/10.1891/0198-8794.32.115 
Angner, E., Ghandhi, J., Purvis, K., Amante, D., \& Allison, J. (2013). Daily Functioning, Health Status, and Happiness in Older Adults. Journal of Happiness Studies, 14, 1563-1574. doi: 10.1007/s10902-012-9395-6

Arksey H., \& O'Malley L. (2005). Scoping studies: Towards a methodological framework. International Journal of Social Research Methodology, 8, 19-32. doi:10.1080/1364557032000119616

Baker, F.A., \& Ballantyne, J. (2013). "You've got to accentuate the positive": Group songwriting to promote a life of enjoyment, engagement and meaning in aging Australians. Nordic Journal of Music Therapy, 22, 7-24. doi: 10.1080/08098131.2012.678372

Baltes, P. B., \& Smith, J. (2003). New frontiers in the future of aging: From successful aging of the young old to the dilemmas of the fourth age. Gerontology, 49, 123-135. doi:10.1159/000067946

Bangen, K., Meeks, T., \& Jeste, D.V. (2013). Defining and Assessing Wisdom: A Review. American Journal Geriatric Psychiatry, 21, 1254-1266. doi: 10.1016/j.jagp.2012.11.020

Booth, A., Papaioannou, D., \& Sutton, A. (2012). Systematic Approaches to a Successful Literature Review. London: Sage.

Broadbent, J., Quadros-Wander, S., \& McGillivray, J. (2013). Perceived Control's Influence on Wellbeing in Residential Care Versus Community Dwelling Older Adults. Journal of Happiness Studies. doi: 10.1007/s10902013-9452-9.

Brodsky, W. (2011). Rationale behind investigating positive aging among symphony orchestra musicians: A call for a new arena of empirical study. Musicae Scientiae, 15, 3-15. doi: 10.1177/1029864910393425

Brummett, B., Babyak, M., Grønbæk, M., \& Barefoot, J. (2011). Positive emotion is associated with 6-year change in functional status in individuals aged 60 and older. The Journal of Positive Psychology, 6, 216-223. doi:10.1080/17439760.2011.570367

Chaitin, J., Sternberg, R., Arad, H., Barzili, L., Deray, N., \& Shinhar, S. (2013). "I May Look 75, but I'm Really a Pioneer": Concept of Self and Resilience Among Israeli Elder Adults Living in a War Zone. Journal of Happiness Studies, 14, 1601-1619. doi: 10.1007/s10902-012-9398-3.

Cohen-Mansfield, J., \& Poon, L. (2011). An integrative summary and future directions in the study of well-being. In L. Poon \& J. Cohen-Mansfield (Eds.), Understanding Well-being in the Oldest Old (pp.364-377). New York, NY: Cambridge University Press.

Cowlishaw, S., Niele, S., Teshuva, K., Browning, C., \& Kendig, H. (2013). Older adults' spirituality and life satisfaction: a longitudinal test of social support and sense of coherence as mediating mechanisms. Ageing and Society, 33, pp 1243 - 1262. doi: 10.1017/S0144686X12000633,

Dai, B., Zhang, B., \& Li, J. (2013). Protective Factors for Subjective Wellbeing in Chinese Older Adults: The Roles of Resources and Activity. Journal of Happiness Studies, 14, 1225-1239. doi: 10.1007/s10902-0129378-7

Delle Fave, A., Brdar, I., Freire, T., Vella-Brodrick, D., \& Wissing, M.P. (2011). The eudaimonic and hedonic components of happiness: Qualitative and quantitative findings. Social Indicators Research, 100, 158-207. doi: 10.1007/s11205-010-9632-5

Diener, E., Emmons, R., Larsen, R., \& Griffin, S. (1985). The Satisfaction With Life Scale. Journal of Personality Assessment, 49, 71-75.

Diener, E., Suh, E. M., Lucas, R. E., \& Smith, H. L. (1999). Subjective wellbeing: Three decades of progress. Psychological Bulletin, 125, 276-302.

Etezadi, S., \& Pushkar, D. (2013). Why are Wise People Happier? An Explanatory Model of Wisdom and Emotional Well-Being in Older Adults. Journal of Happiness Studies, 14, 929-950. doi: 10.1007/s10902012-9362-2

Gana, K., Bailly, N., Saada, Y., Joulain, M., \& Alaphilippe, D. (2013)a. Does life satisfaction change in old age: Results from an 8-year longitudinal study. The Journals of Gerontology, Series B: Psychological Sciences and Social Sciences, 68, 540-552, doi:10.1093/geronb/gbs093

Gallagher, M., Lopez, S., \& Preacher, K. (2009). The Hierarchical Structure of Well-Being. Journal of Personality, 77, 1025-1050. doi: 10.1111/j.14676494.2009.00573.x

Gana, K., Bailly, N., Saada, Y., Joulain, M., Trouillet, R., ... \& Alaphilippe, D. (2013)b. Relationship Between Life Satisfaction and Physical Health in Older Adults: A Longitudinal Test of Cross-Lagged and Simultaneous Effects. Health Psychology, 32, 896-904. doi: 10.1037/a0031656

Godoy-Izquierdo, D., Moreno, R., Pérez, M., Serrano, F., \& García, J. (2013). Correlates of Happiness Among Older Spanish Institutionalised and Non-Institutionalised Adults. Journal of Happiness Studies, 14, 389414. doi: 10.1007/s10902-012-9335-5

Griffin, P.W., Mroczek, D.K., \& Spiro, A. (2006). Variability in affective change among aging men: Longitudinal findings from the VA Normative Aging Study. Journal of Research in Personality, 40, 942-965. doi:10.1016/j.jrp.2005.09.011

Henderson, L.W., \& Knight, T. (2012). Integrating the hedonic and eudaimonic perspectives to more comprehensively understand wellbeing and pathways to wellbeing. International Journal of Wellbeing, 23), 196-221. doi:10.5502/ijw.v2i3.3

Hill, R. (2005). Positive Aging: A Guide for Mental Health Professionals and Consumers. New York: W. W. Norton \& Company.

Horner, E. (2012). Subjective Well-Being and Retirement: Analysis and Policy Recommendations. Journal of Happiness Studies. doi: 10.1007/s10902012-9399-2

Isaacowitz, D.M., Vaillant, G.E., \& Seligman, M.E.P. (2003). Strengths and Satisfaction Across The Adult Lifespan. International Journal of Aging and Human Development, 5), 181-201. doi:10.2190/61EJ-LDYR-Q55N-UT6E

Jeste, D.V., \& Palmer, B.W. (2013). A call for a new positive psychiatry of ageing. The British Journal of Psychiatry, 202, 81-83. doi: 10.1192/bjp.bp.112.110643

Kapur, N., Cole, J., Manly, T., Viskontas, I., Ninteman, A., Hasher, L., \& Pascual-Leone, A. (2013). Positive Clinical Neuroscience: Explorations in Positive Neurology. The Neuroscientist, 19, 354-369. doi: $10.1177 / 1073858412470976$

Keng, S., \& Wu, S. (2013). Living Happily Ever After? The Effect of Taiwan's National Health Insurance on the Happiness of the Elderly. Jour nal of Happiness Studies. doi: 10.1007/s10902-013-9449-4

Keyes, C., Shmotkin, D., \& Ryff, C. (2002). Optimizing Well-Being: The Empirical Encounter of Two Traditions. Journal of Personality and Social Psychology, 82, 1007-1022. doi: 0.1037//0022-3514.82.6.1007

Kim, E., Sun, J., Park, N., \& Peterson, C. (2013)a. Purpose in life and reduced incidence of stroke in older adults: 'The Health and Retirement Study'. Journal of Psychosomatic Research, 74, 427-432. http://dx.doi.org/10.1016/j.jpsychores.2013.01.013

Kim, E., Sun, J., Park, N, Kubzansky, L., \& Peterson, C. (2013)b. Purpose in life and reduced risk of myocardial infarction among older U.S. adults with coronary heart disease: a two-year follow-up. Journal of Behavioral Medicine, 36, 124-133. doi 10.1007/s10865-012-9406-4

Koopmans, T.A. Geleiinse, J.M., Zitman, F.G, \& Giltay, E.J. (2010). Effects of Happiness on All-Cause Mortality During 15 Years of FollowUp: The Arnhem Elderly Study. Journal of Happiness Studies, 11, 113-124. doi 10.1007/s10902-008-9127-0

Linley, P., Joseph, S., Harrington, S., \& Wood, A. (2006). Positive psychology: Past, present, and (possible) future. The Journal of Positive Psychology, 1 , 3-16. doi: 10.1080/17439760500372796

National Institute on Aging (2013). NLA Timetable. Available in: http://www.nia.nih.gov/about/nia-timeline

Neugarten, B.L., Havighurst, R.J., \& Tobin, S.S. (1961). The Measurement of Life Satisfaction. Journal of Gerontology, 16, $134-143$.

Oishi, S., Whitchurch, E., Miao, F., Kurtz, J., \& Park, J. (2009). 'Would I be happier if I moved?' Retirement status and cultural variations in the anticipated and actual levels of happiness. The Journal of Positive Psychology, 4 , 437-446. doi:10.1080/17439760903271033

Ong, A., Mroczek, D.K., \& Riffin, C. (2011). The Health Significance of Positive Emotions in Adulthood and Later Life. Social and Personality Psychology Compass, 5, 538-551. doi: 10.1111/j.1751-9004.2011.00370.x

Ostir, G.V., Ottenbacher, K.J., \& Markides, K.S. (2004). Onset of frailty in older adults and the protective role of positive affect. Psychology and $A g-$ ing, 19(3), 402-408. doi: 10.1037/0882-7974.19.3.402

Palgi, Y. (2013). Ongoing Cumulative Chronic Stressors as Predictors of Well-Being in the Second Half of Life. Journal of Happiness Studies, 14, 1127-1144. doi: 10.1007/s10902-012-9371-1

Paúl, C. (2007). Old-Old People: Major Recent Findings and the European Contribution to the State of the Art. In: Rócio Férnandez-Ballesteros (Eds.). GeroPsychology: European Perspectives for an Aging World. Germany: Hogrefe and Huber, pp. 128-144.

Payne, L.L. \& Heavenrich, C. (2011). Stop aging and start living: the theory and practice of positive aging. International Journal on Disability and Human Development, 10, 97-101. doi: 10.1515/IJDHD.2011.024 
Peterson, S., \& Spiker, B. (2005). Establishing the Positive Contributory Value of Older Workers: A Positive Psychology Perspective. Organizational Dynamics, 34, 153-167. doi: 10.1016/j.orgdyn.2005.03.002

Peterson, T., Chatters, L., Taylor, R., \& Nguyen, A. (2013). Subjective WellBeing of Older African Americans with DSM IV Psychiatric Disorders. Journal of Happiness Studies. doi: 10.1007/s10902-013-9470-7

Post, S. (2005). Altruism, Happiness, and Health: It's Good to Be Good. International Journal of Behavioral Medicine, 12, 66-77.

Ramírez, E., Ortega, A., Chamorro, A., \& Colmenero, J. (2013). A program of positive intervention in the elderly: memories, gratitude and forgiveness. Aging \& Mental Health. http://dx.doi.org/10.1080/13607863.2013.856858.

Rejeski, W.J., \& Gauvin, L. (2013). The embodied and relational nature of the mind: implications for clinical interventions in aging individuals and populations. Clinical Interventions in Aging, 8, 657-665. doi: 10.2147/CIA.S44797

Robertson, G. (2012). Positive ageing - from the political to the Personal. Working with older people, 16, 149-153. doi: 10.1108/13663661211286675

Ruch, W., Proyer, R.T., \& Weber, M. (2010). Humor as a character strength among the elderly. Theoretical considerations. Zeitschrift für Gerontologie und Geriatrie, 43, 8-12. doi: 10.1007/s00391-009-0080-2

Rowe, J. W., \& Kahn, R. L. (1997). Successful Aging. The Gerontologist, 37, 433-40. doi: 10.1093/geront/37.4.433

Ryan, R.M., \& Deci, E.L. (2001). On happiness and human potentials: a review of research on hedonic and eudaimonic well-being. Annual Review of Psychology, 52, 141-166.

Ryff, C. D. (1989). Beyond Ponce de Leon and life satisfaction: New directions in quest of successful aging. International Journal of Behavioral Development, 12, 35-55.

Ryff, C. D. (2003). Corners of myopia in the positive psychology parade. Psychological Inquiry, 14, 153-159

Ryff, C. D., \& Keyes, C.L. (1995). The Structure of Psychological WellBeing Revisited. Journal of Personality and Social Psychology, 69,719-27.

Rodgers, W.L., \& Herzog, A.R. (1992). Collecting data about the oldest: problems and procedures. In R.M., Suzman, D.P. Willis, \& K.G. Manton (Eds.), The Oldest Old (pp. 135-56). New York: Oxford University Press.

Seligman, M.E.P., \& Csikszentmihalyi, M. (2000). Positive psychology: an Introduction. American Psychologist, 55, 5-14.

Seligman, M.E.P. (2008). Positive Health. Applied Psychology: An International Review, 57, 3-18. doi: 10.1111/j.1464-0597.2008.00351.x

Schilling, O., Wahl, H., \& Oswald, F. (2013). Change in Life Satisfaction under Chronic Physical Multi-morbidity in Advanced Old Age: Potential and Limits of Adaptation. Journal of Happiness Studies, 14, 19-36. doi: 10.1007/s10902-011-9313-3
Swindells, R., Lawthom, R., Rowley, K., Siddiquee, A., Kilroy, A., \& Kagan, C. (2013). Eudaimonic well-being and community arts participation. Perspectives in Public Health, 133, 60 - 67. doi: 10.1177/1757913912466948

Tadic, M., Oerlemans, W., Bakker, A., \& Veenhoven, R. (2013). Daily Activities and Happiness in Later Life: The Role of Work Status. Journal of Happiness Studies, 14, 1507-1527. doi: 10.1007/s10902-012-9392-9

Tovel, H., \& Carmel, S. (2013). Maintaining Successful Aging: The Role of Coping Patterns and Resources. Journal of Happiness Studies. doi: $10.1007 / \mathrm{s} 10902-013-9420-4$

Tweed, R. G., \& Tweed, C. J. (2011). Positive emotion following spousal bereavement: Desirable or pathological? Journal of Positive Psychology, 6, 131141. doi: $10.1080 / 17439760.2011 .558846$

Vahia, I., Chattillion, E., Kavirajan, H., \& Depp, C. (2011). Psychological Protective Factors Across the Lifespan: Implications for Psychiatry. Psychiatric Clinics of North America, 34, 231-248. doi: 10.1016/j.psc.2010.11.011

Vaillant, G. (2002). Aging Well: Surprising Guideposts to a Happier Life. USA: Little Brown.

Veenhoven, R. (2008). Healthy happiness: effects of happiness on physical health and the consequences for preventive health care. Journal of Happiness Studies, 9, 449-469. doi: 10.1007/s10902-006-9042-1

Waterman, A.S. (1993). Two conceptions of happiness - contrasts of personal expressiveness (eudaimonia) and hedonic enjoyment. Journal of Personality and Social Psychology, 64, 678-691. doi: 10.1037/00223514.64.4.678

Wiesmann, U., \& Hannich, H. (2013)a. The Contribution of Resistance Resources and Sense of Coherence to Life Satisfaction in Older Age. Journal of Happiness Studies, 14, 911-928. doi: 10.1007/s10902-012-9361-3

Wiesmann, U., \& Hannich, H. (2013)b. A Salutogenic Analysis of the WellBeing Paradox in Older Age. Journal of Happiness Studies. doi: 10.1007/s10902-013-9425-z

Wood, A.M., \& Joseph, S. (2010). The absence of positive psychological (eudemonic) well-being as a risk factor for depression: A ten year cohort study. Journal of Affective Disorders, 122, 213-217. doi: 10.1016/j.jad.2009.06.032

World Health Organization (2011). Global Health and Aging. Available in: http://www.who.int/ageing/publications/global_health.pdf

Wolverson, E.L., Clarke, C., \& Moniz-Cook, E. (2010) Remaining hopeful in early-stage dementia: A qualitative study. Aging \& Mental Health, 14, 450-460. doi: 10.1080/13607860903483110

(Article received: 03-08-2016; revised: 10-12-2016; accepted: 26-12-2016) 